\title{
sciendo
}

\section{Romanian public authorities request unnecessary approvals for urbanism permits}

\author{
Simona CHIRICĂ \\ Bucharest University of Economic Studies, Bucharest, Romania \\ simona.chirica@drept.ase.ro
}

\begin{abstract}
This work draws the attention of a wide and illegal practice developed by some Romanian public authorities. This practice if the public authorities to requests additional approvals that are not provided in the legislation generates unjustified delays and significant costs for the beneficiaries of the construction works. Thus, in the phase of drafting the urbanism documentation, some city halls and local councils request the neighbours approval in notarized form as a prerequisite for approval of the zonal urbanism plans ("PUZ") and / or of the detail urbanism plans ("PUD"). As this approval does not reflect a mandatory condition according to the legal framework that regulates the procedure for drafting and approval of the urbanism documentation, the practical effect is that, as a consequence of a wrongful interpretation of the law by some public authorities, the beneficiaries of the construction works lead in useless situations in which they depend on the discretionary will and sometimes also abusively of their neighbours.
\end{abstract}

Keywords: town planning certificate, PUZ, PUD, neighbors' approval, Law 50/1991, law 350/2001.

\section{A clear legislative distinction, but apparently wrongly understood}

It is important to reveal that the current legal framework applicable to drafting and approval of the urbanism documentation (i.e. Law no. 350/2001 regarding territory and urbanism landscaping ("Law 350") and its corresponding methodological norms) does not indicate any mention through which the approval of the urbanism documentation should be conditioned by obtaining the neighbours approval. Besides, such proceeding would be redundant because the request of the neighbours approval in the phase of the approval of the urbanism documentation has no justification as the neighbours (among other persons) have the opportunity to express their point of view and to raise objections on the impact of PUD/PUZ in the phase of public debate regarding having as object such urbanism documentation in accordance with art 36-41 of the Order no 2701/2010 for approval of the Methodology on information and public debate regarding the drafting and review of the territory and urbanism landscaping.

On the other side, we note that the only normative act that rules the obligation to obtain the neighbours approval is Law no. 50/1991 regarding the authorization of the construction works ("Law 50") in the following hypothesis: merger of a construction work to the wall of another construction, the impact of the sunny grade, incompatibilities between the pre-existent function and the new one proposed, etc. However, we note that this law rules the procedure and the afferent documentation for approval of the issuance of the building permit and not for the drafting of the urbanism documentation.

Thus, art. 2 of the Methodological Norms of Law 50 expressly provides that "the drafting, authorization and approval of the documentation regarding territory and urbanism landscaping shall be performed pursuant to Law 350 and of the other laws / norms and does not constitute part of the authorization procedure for the execution of construction works." 
Specifically, the legislator rules expressly under point 2.5.6 of Annex no. 1 of Law 50 the cases in which, depending of the particularities and/or the placement of the new buildings that will be erected, it is mandatory the notarized approval of the neighbours. In this case the Law provides that this is part of the technical documentation for the authorization of the building works ("DTAC"). Hence, as per the above-mentioned legal provisions, the neighbours' approval is mandatory in the following cases: "(i) for the new buildings located adjacent to the existing buildings or in their immediately vicinity - and only if they are required interventions measures for their protection; (ii) for buildings necessary for change of the destination of existing buildings; (iii) in case of locating buildings with other destination that of the neighboured buildings."

Although it results from the above that there are clear differences between the drafting and approval urbanism documentation procedure and the procedure for authorization of construction works, the practice of the public authorities (i.e. the city halls requests in the town planning certificate for PUZ/PUD the obtaining of neighbours approval) reveals that (i) either they do not remark such differences or (ii) in case they distinguish them, they opt for an option that does not expose them to any liability case and thus to potential public / media denigration. We tend to believe that the second assessment is rather the factual explanation. Such public authorities know that any person/investor interested in a development will be reluctant to challenge such illegal requests in front of the courts as they will submit anyhow any request for building permit in the same place (i.e. city hall).

The public authorities need to make the difference between the urbanism certificates issued for drafting the PUZ/PUD, which should not include the neighbour's approval in notarized form and the urbanism certificates issued for construction purposes which shall include or shall not include the neighbours' approval. Such approval shall be requested if it is in one of the cases indicated under point 2.5.6 form the Annex no 1 of Law 50.

Such cases are for example when by erecting a new building in the immediately vicinity of an existing building, it may jeopardize damages from the following point of view: mechanical resistance and stability, fire security, hygiene, health and environment or exploitation safety. The causes of these situations can be, for example, merger of a construction work to the wall of another construction, foundation deeper than the current foundation of an existing building, the impact of the sunny grade. Also, it is required the neighbours' approval in notarized form in the cases in which, through execution of investments may be created discomfort situations. These are triggered also by incompatibilities between the pre-existing and the new proposed function or the incompatibilities between the functionality of a new building does not fit with the functionality of the zone where this building will be integrated. The most frequent causes are those resulting from noise, traffic and traffic emissions, etc.

Unfortunately, regardless the reason, some public authorities apply through analogy the legal provisions regarding the neighbour' approval in notarized form in the case of drafting of urbanism documentation as well as in the authorization of the construction works phase. By this, they are ending up adding to the law, which is a severe infringement to the constitutional rules. The public authorities are part of the executive power of the state and not of the legislative power (i.e. parliament). According to legal scholars, "the legality of the legal acts issues by the public authorities imply the following requests: the legal act should be issued with observance of the competence provided under the law; the legal act should be issues in accordance with the procedure provided by the law; the legal act should observe the legal norms with higher power", respectively "the principle of proportionality is an essential criteria that allows the segregation of discretionary power from the excess of power in the activity of the state authorities.". 
In addition to the before mentioned argument, it may be also said that also the following objective, clear and undoubtful technical argument may be successfully sustained in front of any court of law where such requests may be challenged: in the phase of drafting the urbanism documentation it cannot be the case of damages caused to the neighbours buildings from mechanical and stability resistance reasons, as well as fire security, noise, traffic, traffic emissions, etc, as long as there is no factual technical project of the future building. Only after the technical project will be analysed in the phase of issuance of the building permit, it may be established whether the approval from the neighbours in notarized form is necessary or not.

PICBE | 890

\section{The provisions of the Romanian Civil Code}

The Romanian Civil Code does not regulate situations in which it is necessary to obtain the approval of the neighbors in order to build a construction.

According to the Romanian legislation property owners should be free to exercise unrestricted all attributes of their ownership right. However, the legislator stipulates on the one hand that "the law may limit the exercise of the ownership right either due to public interest or private interest" (article 602 of the Civil Code), respectively "the ownership right obliges the owner to comply with the provisions regarding the protection of the environment and to assure good neighborhood, as well as to the fulfil other duties which, according to the law or the custom, are the owner's responsibility" (article 603 of the Civil Code).

We specify that the Romanian Civil Code provides certain legal limits of the private ownership right that the neighbors shall comply with. Thus, according to the rules of the Civil Code, owners must fulfil the tasks related to environmental protection and good neighborhood.

Regarding the minimum distance between constructions, the Civil Code expressly provides that any constructions, works or plantations may be made by the owner of the property only with respect to a minimum distance of $60 \mathrm{~cm} / 23,6$ inch from the border line, unless otherwise provided by law or by town planning regulations, so as not to infringe the rights of the neighboring owner. Obviously, the Civil Code allows derogations from the minimum distance of the properties that can be agreed by the parties under a notarized agreement.

Such limits are also provided in case of the view of the neighbor's property. Therefore, it is mandatory to keep a distance of at least 2 meters between the property, fenced or unfenced, belonging to the neighboring owner and the window, the balcony or other such works that would be oriented towards its property. The window, the balcony or other such works which are not parallel with the border line to the neighboring land are prohibited at a distance of less than one meter. In this case, it is also possible to derogate from the provisions provided by the Civil Code, also with the approval of the neighbor in notarized form.

\section{Legal risks and solutions}

By imposing an additional condition for the approval of the urbanism documentation, which is not provided by law, the public authorities disregard the intentions of the legislator and unacceptably extend the scope of the urban planning provisions.

By adding a condition for the approval of the PUZ/PUD, which is not provided by law, the public authorities add to the law in a discretionary, illegal and, ultimately, abusive way.

Moreover, this administrative approach is not allowed under the new regulations in force, i.e. the provisions of article 5 para. (4) of Law 50, recently amended on the basis of Law 193/2019, which expressly provides that "the approvals / conditions required by the urbanism certificate must 
refer strictly to the type of works necessary for the construction, being prohibited to request other approvals /conditions that do not have a technical and legal basis."

Obviously, this practice of certain public authorities to impose additional requirements by the town planning certificate, which are not necessary in the phase of the approval of the urbanism documentation, triggers practical problems for investors, resulting in delays and unjustified costs in connection with the development of their real estate projects.

It is difficult to understand the reason behind this practice of the public authorities and, in particular, the interest which the public authorities apparently try to protect. Moreover, the absence of an express sanction (such as the nullity of the town planning certificate, or the nullity of the PUZ/PUD) for such additional conditions cannot be invoked, as there is no provision in relation to this. Therefore, the 'fight' with the authorities in such situations can be carried out by the investor only on the basis of the argument that he assumes that the relevant urbanism documentation will be issued without the approval of the neighbors, in case of a dispute. Basically, investors are forced to accept this situation (Draganu, 1999).

We think that this situation should be subject to the control of the courts, and investors shall claim their rights by filing an action against the public authorities in front of the courts which are competent in the field of administrative law. The courts will thus be able to annul the illegal acts and oblige the public authorities to issue town planning certificates in accordance with the legal provisions and by this to abolish an illegal and damaging practice (Alexandresco, 2009).

Unfortunately, in practice, investors are forced to weight the waste of time and costs in the event of a dispute versus those arising from the abusive requirements of public authorities and, in most cases, they will opt for the latter one.

We have to say that the latter one is not necessarily the shortest way, especially if one or more neighbors refuse to give their approval. In such a situation, investors still have the opportunity to fulfil their rights in court under article 27 para. (6) of the Methodological Norm for the application of Law 50, according to which "If unjustified refusal of the neighbors to give their approval is found by the competent court, the latter one will rule a decision which shall be accepted by the public authorities instead of the neighbors' approval". In this case, investors will have to prove that they are not in one of the situations provided by point 2.5.6 of Annex no. 1 to Law 50 and that the neighbour abusively refuses to issue its construction approval required by the law.

Therefore, the investor will have to prove that (i) no intervention measures are necessary to protect the neighboring building and / or (ii) that the investment does not affect the housing function due to noise, traffic, emissions, etc. Moreover, in some cases, investors shall demonstrate that neighbors may even make their approval conditional to receiving money or abusively and in bad faith impose other conditions to the investors.

In case the neighbours are in one of the situations, provided by Law 50, for which the construction approval is required, then the investor has the obligation to ensure, through the technical project P.Th. and the building / demolition permit, the measures for securing the pre-existing construction (of the neighbor) resulting from the technical expertise report drawn up at the order of the investor.

Therefore, the neighbours can impose the investor to draw up the technical expertise report in order to establish the necessary measures for securing their property, and shall condition to give their construction approval only after the safety measures have been implemented by the investors. 


\section{Conclusions}

In conclusion, in case public authorities require investors, under the town planning certificate for the approval of the urbanism documentation, to obtain the construction approval of their neighbors in notarized form, it is important that they understand that this requirement is illegal and that the town planning certificate issued by the public authority can be challenged in court.

However, we consider that, "de lege ferenda", a legislative clarification is required meaning that the law should expressly stipulate that the notarized approval of the neighbors will be necessary only in the phase of issuance of the building permit and only in the special cases expressly mentioned by law.

We also consider that the law should detail the hypotheses in which neighbors may refuse their approval and should provide, by way of example, what concrete safety measures should be taken by the investors.

\section{References}

Law no. 350/2001 regarding territory and urbanism landscaping was published in the Official Journal Part I, no. 373, $10^{\text {th }}$ July 2001.

Law 50/1991 regarding the authorization of the construction works was published in the Official Journal Part I, no. 933 date 13.10.2004.

Draganu, T. (1999). Drept constituţional şi instituţii politice-tratat elementar, vol. I, Constitutional Law, România de Mâine" Foundation's Press, Bucharest, 5.

Alexandresco, D. (1909). Explicaţiunea teoretică şi practică a dreptului civil român, tomul III, partea I, ed. a 2-a, Bucureşti, 1909, p. 230; apud C. Bîrsan, Drept civil. Drepturile reale principale, Editura Hamangiu, Bucureşti, 2013, p. 43. 